\title{
REGIONAL SUSTAINABILITY OF LOCAL AND RURAL DEVELOPMENT
}

\author{
Mladenka Balaban ${ }^{1}$, Slobodan S. Župljanin ${ }^{2}$, Dragana Nešović3 \\ *Corresponding author E-mail: mladenka.balaban@bba.edu.rs
}

A R T I C L E I N F O

Review Article

Received: 04 November 2019

Accepted: 10 December 2019

doi:10.5937/ekoPolj1904173B

UDC 332.1:338.435

Keywords:

sustainable development, rural region, region, local community, regional development

JEL: R2, P25
A B S T R A C T

The paper examines the essential preconditions for the sustainable development of local and rural communities, as well as the obstacles faced by developing and countries in transition. This paper aim is to identify, through a comparative analysis of countries in the region and Serbia, the real potential for sustainable and rural development, starting from regional competitiveness and national development strategies. The method of comparing data on economic and demographic trends and basic parameters of growth functioning in certain groups of countries wants to point out the specificities of sustainable growth of individual economies. The research results show that a long-term imbalance of inputs and outputs is created due to the lack of a concept of sustainability which causes irrational use of resources and energy. Started of the fact that all countries in the region generally have high quality natural, cultural and traditional heritage, as well as respectable renewable resources, the emphasis in the coming period must be on developing level strategies that will be based on the rational management of natural resources so that they can be achieved better sustainable development results.

(C) 2019 EA. All rights reserved.

\section{Introduction}

In the last decades of development, the global economy has undergone various changes, often very dramatic. The conditions for acquiring and maintaining competitive advantage and ways to create and increase wealth have changed. These changes were

1 Mladenka Balaban, Professor, Belgrade Banking Academy, Zmaj Jovina 12, 11000 Belgrade, phone number+38169310572, e-mail mladenka.balaban@bba.edu.rs, ORCID ID 0000-0003-0170-6622

2 Slobodan S. Župljanin, Professor, Independent University, Faculty of Economic, 78000 Banja Luka, BIH, phone number +38765663468, e-mail slobodan.zupljanin@nubl.org, ORCID ID 0000-0002-4064-3129

3 Dragana Nešović, Assistance Professor, Faculty of Law, Security and Traffic Management, Zetska 3, 18000 Niš, Republic of Serbia, phone number .+38162205480, e-mail dragana. nesovich@gmail.com, ORCID ID 0000-0002-1224-9650

http://ea.bg.ac.rs 
reflected in the constant demand for reducing the cost of collecting, disseminating and using information, shortening the life of the product, accelerated technological development, changing consumer habits and needs, accelerated internationalization and business liberalization.

These changes have also affected the overall transformation of the global society, which today is referred to as the "knowledge economy" or "information society". Especially driven by the current economic and financial crisis, new models of economic development based on competitiveness and sustainable development are being developed. „Modern information technologies and new knowledge must be able to create conditions for increasing competitiveness and sustainable development in the long run. This is especially important for countries that have not yet completed the transition process and have not found their clear position on the global stage." (Barbier \& Markandya, 1989.)

Therefore, in this paper, we will point out the basic determinants and importance of sustainable development, the state of sustainable development in the world and the region, and the possibilities of creating and managing local and rural development.

\section{Materials and methods}

Sustainable development - Sustainable development is a fundamental feature of natural resource and environmental economics. There are different approaches and definitions of sustainable development. Nevertheless, it is central to elaborating on the long-term perspective of humanity's survival and development. Humanity's activity is unthinkable without sustainable development.

The classical theory is the first to analyze and define the concept of sustainable development. Smith, Ricardo, and Malthus, as economic classics, studied and analyzed the limitations of natural resources, declining production yields, and demographic growth. In the early stages of the development of economic thought, the idea of the necessity of a long-term unchanged state emerged, without economic and demographic growth - a zero growth rate of the economy and society was proposed as the only possible and stable one. This thesis of development was later negated by many economic schools and directions.

At the end of the 19th century, technological advances and new scientific discoveries offered a more optimistic vision of the future of humanity. Then there is talk in scientific circles of the need to analyze the optimal use of exhaustive resources.

In the twentieth century, the neoclassical theory of growth emerged, which radically negated the zero growth of the economy and society, and the question of the exhaustion of natural resources lost importance. Technical and technological progress is considered to be a fundamental factor in the development of the economy and society. This belief was contributed by the decades-long growth of numerous economies since World War II. 
The seventies of the twentieth century refute such understandings and beliefs. The first oil crises are occurring, accompanied by rising world prices for many raw materials and energy inputs. The issue of resource exhaustion and growth is now being re-actualized. The international public is preoccupied with issues related to the concept and strategy of sustainable development.

Numerous reasons determine activities by state and non-governmental organizations around the world led in 1992 to the United Nations Conference on Environment and Development - UNCED in Rio de Janeiro, which adopted numerous environmental and sustainable development documents.

Defining a sustainable development strategy is one of the very important aspects of humanity's survival and development. The basis for sustainable development lies in the fact that economic activities must be sustainable.

It seems logical and just to make the moral demand that the present generation leaves to future generations no less opportunity for development than what it has today. The right of the present generation to exploit resources must not jeopardize the same right to future generations.

Environmental protection is the basis and the need for sustainable development. Various theories point to the fact that man is part of nature, which has value, and as part of it has no right to irreversibly change it and adversely affect it. Bearing in mind this fact, man as such has an obligation to generations and also to nature as a whole.

A third important reason for sustainable development is the efficient use of available resources. Failure to adhere to the concept of sustainability certainly leads to poor development, that is, irrational use of resources and energy, thus creating a long-term imbalance of growth results in the national economy as a whole.

Sustainable development in the world - The concept of sustainable development is a serious milestone in the global approach to development and environmental protection. This concept is based on the fact that there must be a responsibility for environmental protection, but also for the responsibility of present generations to future generations. Sustainable development stands out in three aspects:

Environmental Aspect - "An environmentally sustainable system must have the capability to keep resources stable (renewable resources not overexploited and nonrenewable according to the possibility of finding a suitable replacement) without compromising their vital function. Such a requirement implies maintaining biodiversity, the stability of the atmosphere, and the functions of other ecosystems, which are not economic resources." (Beard \& Lozada, 1999).

Social aspect - "Sustainable society must distribute capital in such a way as to ensure adequate provision of services in all spheres of social life. These include the social aspect, health, education, culture, gender equality, political action and all forms of responsibility" (Pejanović et. al., 2007). In underdeveloped countries, 
the natural environment is more threatened, the reason being that highly developed countries are relocating their production to these countries, using cheaper human and natural resources. Domestic authorities pressure foreign companies to comply with environmental standards and sustainable development requirements.

Table 1. - Characteristics of growth in an undeveloped country

\begin{tabular}{|c|c|c|c|c|c|c|c|c|c|c|}
\hline \multirow{3}{*}{ Region } & \multicolumn{5}{|c|}{$\begin{array}{l}\text { Frecuencyand the duration of } \\
\text { growth period }\end{array}$} & \multicolumn{5}{|c|}{$\begin{array}{l}\text { Awerage growthbefore, duringand after } \\
\text { growth period }\end{array}$} \\
\hline & \multirow{2}{*}{$\begin{array}{l}\text { No. of } \\
\text { countries }\end{array}$} & \multirow{2}{*}{$\begin{array}{l}\text { No.of } \\
\text { periods }\end{array}$} & \multirow{2}{*}{$\begin{array}{c}\text { Mean } \\
\text { duration } \\
\text { (years) }\end{array}$} & \multicolumn{2}{|c|}{$\begin{array}{l}\text { \% Periodslasting } \\
\text { at least }\end{array}$} & \multicolumn{3}{|c|}{ Awerage growth } & \multicolumn{2}{|c|}{$\begin{array}{c}3 \\
\text { years }\end{array}$} \\
\hline & & & & 10 years & 16 years & Before & During & After & Before & During \\
\hline \multicolumn{11}{|c|}{ Complete growth period } \\
\hline $\begin{array}{l}\text { Developed } \\
\text { countries }\end{array}$ & 37 & 2 & 13.0 & 100.0 & 00.0 & 3.3 & 6.0 & 1.2 & 2.6 & 3.4 \\
\hline $\begin{array}{c}\text { Developing } \\
\text { countries in } \\
\text { Asia }\end{array}$ & 22 & 3 & 18.0 & 33.3 & 33.3 & -0.7 & 9.1 & 1.4 & 1.4 & 1.9 \\
\hline $\begin{array}{l}\text { Latin } \\
\text { America }\end{array}$ & 18 & 5 & 14.4 & 60.0 & 40.0 & 1.1 & 4.8 & 1.3 & 1.3 & -1.3 \\
\hline $\begin{array}{l}\text { Sub-Saharan } \\
\text { Africa }\end{array}$ & 43 & 3 & 8.3 & 00.0 & 00.0 & -2.7 & 9.9 & -4.0 & -11 & -6.5 \\
\hline $\begin{array}{c}\text { Other } \\
\text { countries in } \\
\text { development }\end{array}$ & 20 & 7 & 10.7 & 42.9 & 14.3 & -1.6 & 5.0 & -0.9 & -1.4 & -2.0 \\
\hline \multicolumn{11}{|c|}{ Total (including the full period of growth) } \\
\hline $\begin{array}{l}\text { Developed } \\
\text { countries }\end{array}$ & 37 & 11 & 24.4 & 100.0 & 63.6 & 0.7 & 5.7 & N.a & -0.1 & N.a \\
\hline $\begin{array}{c}\text { Developing } \\
\text { countries in } \\
\text { Asia }\end{array}$ & 22 & 16 & 24.2 & 87.5 & 56.2 & -0.3 & 5.8 & $\mathrm{~N} . \mathrm{a}$ & 0.4 & N.a \\
\hline $\begin{array}{c}\text { Latin } \\
\text { America }\end{array}$ & 18 & 7 & 15.7 & 71.4 & 42.9 & 0.4 & 4.4 & N.a & 0.1 & N.a \\
\hline $\begin{array}{l}\text { Sub-Saharan } \\
\text { Africa }\end{array}$ & 43 & 18 & 13.6 & 66.7 & 22.2 & 4.0 & 6.3 & N.a & 7.7 & $\mathrm{Na}$ \\
\hline $\begin{array}{c}\text { Other } \\
\text { countries in } \\
\text { development }\end{array}$ & 20 & 12 & 13.5 & 66.7 & 33.3 & -2.1 & 5.0 & $\mathrm{~N} \cdot \mathrm{a}$ & 2.8 & N.a \\
\hline
\end{tabular}

Source: Krstić et al., 2018.

In developing countries and non-developed countries, growth can be very uneven. The previous table gives an example of the sustainability of growth in developing countries in Africa, Latin America, and Asia. Sustainable growth in these countries is variable, as indicated by data over the observed period. However, some studies show that many countries have long declines and even depressions for this long year's growth, which is the case with Africa (Krstić et al., 2018).

Sustainable development in the EU and region -, The goal of sustainable development is to meet the needs of today's generations without compromising the ability of future generations to meet their own needs. Sustainable development involves a comprehensive approach in which economic, social and environmental aspects are integrated and mutually reinforcing. The UN Program by 2030, which was accepted by world leaders in 2015, is a new global framework for sustainable development and sets out 17 sustainable development goals. It represents a commitment to eradicating poverty and achieving sustainable development by 2030 worldwide, leaving no one at a disadvantage. The EU is in a favorable starting position when it comes to sustainable development and is fully committed, together with its Member States, to a leading role in the implementation of the UN Program by 2030 Key measures for the implementation of the Program by 2030: 
$\checkmark$ mainstreaming sustainable development goals into EU policies and initiatives at all levels, with

$\checkmark \quad$ sustainable development being a necessary guiding principle in all European Commission policies

$\checkmark \quad$ regular reporting on EU progress since 2017

$\checkmark$ progress in implementing the Program by 2030 in cooperation with EU governments, the European Parliament, other European institutions, international organizations, civil society organizations, citizens and other stakeholders

$\checkmark$ launching a high-level multi-stakeholder platform to support the exchange of best practices in implementation across sectors at national and EU level

$\checkmark$ developing a longer-term vision for the post-2020 period. (European Commission Report, 2016)

The problem of rural growth sustainability of the European Union includes three components - economic, ecologic and social. Less favorable economic parameters are characteristic for the rural environment of Eastern and Central European countries when it comes to the members of the European Union, while the most advantageous economic indicators occur in Western and Southern European countries. Besides that, the worst ecologic parameters are possessed by some of the older members of the EU (Đokić, 2019).

Few countries in the region are serious about sustainable development. This is confirmed by the fact that some of the countries have not adopted their development strategies, and especially not sustainable development strategies. "To analyze the state of sustainable development, we will elaborate on the situation and situation in the countries of the former Yugoslavia before its dissolution and today. Industrial companies of the former Yugoslavia made full use of installed capacity. The production facilities worked in two shifts, and often in three shifts. The production programs were, for the most part, exportoriented, almost equal to the western and eastern markets". (Bogdanov, 2007).The production programs were licensed - they were made under the licenses of well-known international companies, and there were companies established under the Joint Venture model. There were also direct purchases and technology transfers to our businesses. Thus, some of the world's leading companies have become domestic partners.

The manufacturing facilities are equipped with state-of-the-art proprietary and foreign technology to produce complex and highly-characterized products for the international market. A foreign partner used cheap domestic labor, on the one hand, supplying key materials or semi-finished products assembled in our manufacturing facilities. Domestic companies have achieved significant technical and technological development. This development has been accompanied by employment growth, productivity growth, which has created a better competitive position. Some of the companies have achieved significant technical and technological development, while others have remained at the initial level 
of knowledge and ability. True, competitiveness was maintained with a low personal income of employees, poor protection at work, poor general working conditions and, nevertheless, slow technical and technological development. Sustainable development has stagnated due to further privatization, lack of quality financial resources, lack of modern technologies. With this in mind, it is necessary to work on improving the conditions of sustainable development through the growth of investments, defining development plans, investing in the environment and rational use of available resources, as well as raising awareness and responsibility of present generations. The starting point for sustainable development is the development strategy of the Republic of Serbia, followed by the sustainable development strategy, which defines sectoral development policies including various projects contributing to sustainable development.

\section{Results}

Competitive and innovative ability - Global Competitiveness Index (GSI) measures the set of institutions, policies, and factors that set the sustainable current and mediumterm levels of economic prosperity. Competitiveness is the set of institutions, policies, and factors that determine the level of productivity of an economy, which in turn sets the level of prosperity that the country can achieve. The GCI combines 114 indicators that capture concepts that matter for productivity and long-term prosperity.

These indicators are grouped into 12 pillars: institutions, infrastructure, macroeconomic, environment, health and primary education, higher education and training, goods market efficiency, labor market efficiency, financial market development, technological readiness, market size, business sophistication, and innovation. These pillars are in turn organized into three sub-indexes: Basic requirements, efficiency enhancers, and innovation and sophistication factors (Schwab, 2017).

According to the Global Competitiveness Report 2015 - 2017, WEF, among the top ten most competitive countries in the world by the WEF GCI method, is Switzerland in 2015-2017. took the number one place. For eight years in a row, Switzerland has been ranked first on 4 pillars: labor market efficiency, business sophistication, innovation, and technology. The most innovative country was Japan, which ranked sixth in 2015 2016 in terms of competitiveness, ranking 8th in 2016-2017.

Table 2. Review of competitiveness 2015-2017

\begin{tabular}{|l|c|c|c|c|}
\hline \multirow{2}{*}{ Country } & \multicolumn{2}{|c|}{ 2016-2017 } & \multicolumn{2}{c|}{ 2015-2016 } \\
\cline { 2 - 5 } & $\begin{array}{c}\text { GSI } \\
\text { (score 1-7) }\end{array}$ & Rang & $\begin{array}{c}\text { GSI } \\
\text { (score 1-7) }\end{array}$ & Rang \\
\hline Switzerland & 5.81 & 1 & 5.76 & 1 \\
\hline Singapore & 5.72 & 2 & 5.68 & 2 \\
\hline United States & 5.7 & 3 & 5.61 & 3 \\
\hline Netherlands & 5.57 & 4 & 5.5 & 5 \\
\hline Germany & 5.57 & 5 & 5.53 & 4 \\
\hline Sweden & 5.53 & 6 & 5.43 & 9 \\
\hline United Kingdom & 5.49 & 7 & 5.43 & 10 \\
\hline
\end{tabular}




\begin{tabular}{|l|c|c|c|c|}
\hline \multirow{2}{*}{ Country } & \multicolumn{2}{|c|}{ 2016-2017 } & \multicolumn{2}{c|}{ 2015-2016 } \\
\cline { 2 - 5 } & $\begin{array}{c}\text { GSI } \\
\text { (score 1-7) }\end{array}$ & Rang & $\begin{array}{c}\text { GSI } \\
\text { (score 1-7) }\end{array}$ & Rang \\
\hline Japan & 5.48 & 8 & 5.47 & 6 \\
\hline Hong Kong & 5.48 & 9 & 5.46 & 7 \\
\hline Finland & 5.44 & 10 & 5.45 & 8 \\
\hline
\end{tabular}

Source: Authors creation by Retrieved data from The Global Competitiveness Report 2016-2017

The review presented shows that the Nordic countries have taken a high place in terms of competitiveness. If we analyze more deeply the situation in these countries, then we can conclude that these countries have for years been well politically governed, have welldeveloped market institutions, sound macroeconomic policies, but also rational higher education, vocational training and education, rule of law, efficiency of judicial institutions, efficient public administration and developed infrastructure. Such performance enables them to be highly productive, which is interrelated with the use of modern technologies and innovation. In developing economic and development policies, the focus is on those areas and indicators that contribute more to international competitiveness.

Table 3. Review of competitiveness in 2018

\begin{tabular}{|l|c|c|}
\hline \multirow{2}{*}{ Country } & \multicolumn{2}{|c|}{$\mathbf{2 0 1 8}$} \\
\cline { 2 - 3 } & GSI (score 0-100) & Rang \\
\hline United States & 85.6 & 1 \\
\hline Singapore & 83.5 & 2 \\
\hline Germany & 82.8 & 3 \\
\hline Switzerland & 82.6 & 4 \\
\hline Japan & 82.5 & 5 \\
\hline Netherlands & 82.4 & 6 \\
\hline Hong Kong & 82.3 & 7 \\
\hline United Kingdom & 82.0 & 8 \\
\hline Sweden & 81.7 & 9 \\
\hline Denmark & 80.6 & 10 \\
\hline
\end{tabular}

Source: Authors creation by Retrieved data from The Global Competitiveness Report 2018

In 2018, the method of calculating the competitiveness index is based on a new methodology. ,With the inclusion of new concepts and extensive new data-gathering efforts, the GCI 4.0 provides novel and more nuanced insights on the factors that will grow in significance as the 4IR gathers pace: human capital, innovation, resilience, and agility. These qualities are captured through several new, critically important concepts (e.g. entrepreneurial culture, companies embracing disruptive ideas, multistakeholder collaboration, critical thinking, meritocracy, social trust) complementing more traditional components (e.g. ICT and physical infrastructure, macroeconomic stability, property rights, years of schooling). GCI 4.0 introduces a new progress score ranging from 0 to 100”. (Schwab, 2018).

According to the new methodology, the ranking of countries according to competitiveness has changed, now the first in the competitiveness index is the United States of America, 
followed by Singapore, Germany, Switzerland, Japan. It can be observed that the Scandinavian countries, which have had a high level of competitiveness in recent years due to the steady economic development, remain in the lead in competitiveness.

Table 4. Value IGK by pillars of competitiveness (2017-2018)

\begin{tabular}{|l|c|l|c|}
\hline & 2017 & Change & 2018 \\
\hline Institutions & 53 & $\searrow$ & 51.6 \\
\hline Infrastructure & 71.9 & $\nearrow$ & 73 \\
\hline Adoption of ICT & 55.3 & $\nearrow$ & 56.9 \\
\hline Macroeconomic stabilization & 70 & $\nearrow$ & 75 \\
\hline Health care & 89.9 & $\nearrow$ & 81.5 \\
\hline Skills & 65.7 & $\nearrow$ & 67.5 \\
\hline The goods market & 54.7 & $\nearrow$ & 56.5 \\
\hline Job market & 60.5 & $\nearrow$ & 61.5 \\
\hline The financial system & 51.9 & $\nearrow$ & 55.9 \\
\hline Market size & 50.2 & $\nearrow$ & 50.7 \\
\hline Business Dynamics & 59.3 & $\nearrow$ & 60.9 \\
\hline The ability to innovate & 37.1 & $\nearrow$ & 39.7 \\
\hline
\end{tabular}

Source Tanaskovic, 2018.

Today, Serbia ranks 65th in terms of competitiveness indicator, out of 140 countries observed in the world. If the previous period is analyzed, in 2007 Serbia was 97th according to the Competitiveness Index and held this position for 5 years. Bearing in mind that the macroeconomic environment has improved significantly, ie that the budget deficit has been reduced, that there has been an increase in national savings, an increase in credit rating, which has significantly contributed to the improvement of Serbia's competitive position. The table clearly shows through which pillars Serbia has improved its competitive position, especially in terms of infrastructure, innovation.

Compared to the surrounding countries, Serbia has made the most progress in the last two years, as it ranked 65 th in 2017 with 65.960 .9 index points. The best position in the region in Slovenia, which ranks 35th in the competitiveness index, Hungary 48th, Bulgaria 51st, Romania 52nd, while other countries Croatia, BiH, Macedonia, Montenegro are behind Serbia.

Sustainable local and rural development - Sustainable local rural development is becoming one of the major development priorities of many developing countries. Countries that base their development policies on sustainable local and rural development have a clear vision of their future and demonstrate a responsible attitude in managing the resources available. They practically prove this by creating incentive measures and programs.

The social awareness of the local community is constantly growing. Local communities are increasingly working to raise awareness of the importance of improving the living 
and working conditions of citizens, through raising environmental awareness, making more rational use of natural and energy resources.

There are numerous communities and civil society associations working to raise awareness of the population and the local community as a whole of the need for a rational, scientifically-based balance of available financial, technical and human resources. Some of these institutions and agencies are FDI Promotion Agencies, Export Councils, SME Development Agency, regional and local development agencies, and numerous civil society associations. Special attention was paid to topics related to the better use of renewable and non-renewable sources, as well as to creating a more responsible attitude towards the environment, with full respect for intergenerational solidarity.

In their strategic development plans, local communities should take into account all the factors that can stimulate development, but also those factors that can slow down that development. This approach is very important as financial crises are a common occurrence in the global economy. There are numerous reasons for the local community's interest in sustainable development.

The first reason may be related to the fact that all local development projects require an organized and coordinated action of different levels of local government and local government with state administrations. In order to fulfill local development plans and programs, the roles of all entities as well as the tasks that they must fulfill over a given period of time must be clearly defined. The strategic plan is the starting point The basic prerequisites for creating an adequate strategic plan of the local community are: spatial planning, existence of certain urban and spatial documents, resolved propertylegal relations, existence of partners for the regional component of the project (intermunicipal and cross-border cooperation), quality of municipal infrastructure, minimum funding for the start of the project, etc. Many local communities cannot achieve their strategic plans precisely because of unresolved legal, spatial and urban issues.

Another reason is the ability to access European pre-accession funds (IPAs) through EC Delegations in the Stabilization and Association countries. In addition to being able to use these funds, there is considerable support from experts who, together with various new authorities, are working to develop an administrative environment to absorb these funds in accordance with EU rules.

The third reason is that the preparation and implementation of multi-annual strategic programs, plans and projects involves the involvement of the general public, citizens and their associations, representatives of economic and business associations, as well as formally marginalized social groups in this process. Local community development plans contain both local and rural development as well as a way to implement them. It is very necessary to involve all members of the local community in the creation of the plan, as this ensures easier implementation and realization of strategic goals of local development.

Sustainable local - rural development takes place through continuous development activities, programs, and projects, especially in the following areas:

- Conservation and development integration of the environment, as well as the natural, cultural and traditional heritage, which constitute the local capital and perspectives 
of local community development;

- Development of communal and social infrastructure, and establishment of a supportive development and social environment;

- Economic development - restructuring and development of sustainable agriculture, crafts and small entrepreneurship, diversification of activities and job creation;

- Improving standards and quality of life through developing competitiveness and recognition.

Local capital - Based on the development potential of local communities is precisely the natural, cultural and traditional heritage. The local community should constantly work to preserve these values, but also plan to preserve and maintain their wealth through their developmental perspective.

Every local community should work to protect its wealth and capital, to recognize its value and to put it to the best of its ability in the sustainable development function. To achieve this goal it is necessary to carry out:

- Identification, systematization, and valorization of all values of local heritage;

- To protect, enhance and put into service all valuable elements of local heritage to enable them to be integrated into the function of sustainable development of the local community as an element of its recognition;

- Cultivating the natural environment and preventing the devastation of valuable destinations in the local community.

Communal and social infrastructure - It is unthinkable to develop any local community without developing adequate communal and social infrastructure. As local development in the world is the responsibility of local communities, so local communities are additionally responsible for developing their infrastructure as an indispensable influential factor in economic and social development. Numerous programs and projects for the construction and improvement of local infrastructure are being created in contemporary local communities through the implementation of various instruments of local economic development. In a race to reduce costs and increase competitiveness, the world's most famous companies are moving their capital to cheaper and more infrastructure-ready destinations. In this regard, local communities must:

- Identify local needs effectively with clear dynamics and priorities;

- Plan local infrastructure in line with expected technological developments;

- Dynamically and qualitatively prepare investment projects in the field of utility and social infrastructure;

- Align the local budget with planned projects and find alternative financial sources.

This approach enables local communities to independently create, launch and finance infrastructure projects from local and rural development support funds, in line with good practice in the EU Member States. 


\section{Discussions}

The economic development of local communities - Analyzing the practice of successful regions in the EU, but also in the surrounding countries, we can conclude that the dynamic economic development of local communities is based on a targeted strategic approach and the realization of the following assumptions:

- Identification of local products and services that have the potential to be competitive and constantly create increased added value - creating a local brand;

- Preparation of local development programs, respecting the opportunities of local producers and entrepreneurs to engage in various forms of joint market entry, with a view to joint development of local products and joint market entry; (European Commission Report, 2011)

The basis of the EU sustainable agricultural and rural development policy is the preservation of sufficient stocks of natural, human and financial capital. Thus, parameters that indicate the state of various types of capital and variations in capital stocks are at the beginning of the sustainability indicators list. These indicators are especially important since resources must be reasonably used, considering the uncertainty of substitution between different types of capital, future demand, and possibilities to increase the efficiency of the transformation process (Jovanović, 2018).

Development of entrepreneurial infrastructure, which includes:

- Developing awareness and information on development opportunities and directions,

- Preparation of standard projects,

- Education,

- Construction and establishment of special entrepreneurial zones.

The Ministry of Agriculture of the Republic of Serbia adopted the Strategy of Agriculture and Rural Development for the period 2014-2024 stating that rural areas in the territory of the Republic of Serbia are characterized by a high degree of differentiation in terms of natural, economic, infrastructural and other conditions for agricultural production (which causes its especially the regional aspect), other economic and non-economic activities, proximity to the market and opportunities for market placement of products, as well as in terms of size and morphology of the populated place. The aforementioned diversity points to the heterogeneity of rural space in terms of economic and social development, cultural and demographic characteristics and trends, all of which strongly reflect the quality of life in rural areas.

Areas with difficult working conditions in agriculture are considered the territories of those municipalities which are prescribed by a special regulation defining areas with difficult working conditions in agriculture. According to the aforementioned Rulebook, the status of POURP, for a period of three years, is populated in the territory of the Republic of Serbia which fulfills at least one of the following three criteria, namely: 
- are located at an altitude of 500 and over 500 meters (according to the data of the Republic Geodetic Authority),

- they are within the boundaries of the national park area defined by the National Parks Act ("RS Official Gazette", No. 84/15), and

- have a number of employees that are less than 100 per 1,000 inhabitants (according to data published by Statistical Office of the Republic in the 2015 publication of Municipalities and Regions in the Republic of Serbia) (Ministry of Agriculture, 2014).

Renewable Energy Management - The basic problems of humanity in the 21st century are global warming, environmental pollution, and environmental devastation. These are also the basic developmental issues of the modern world. In these circumstances, the use and management of renewable energy sources (biomass, biogas, solar, wind) and technologies aimed at the sustainable use of available, above all, natural resources become global priorities.

For this reason, EU funds significantly and strongly encourage the development and subsidize the use of renewable energy sources. Practice in the EU shows that local communities investing in renewable energy are experiencing accelerated growth and creating development prospects and ever-increasing competitiveness.

The available natural resources of renewable character in the region are an enormous value that opens new perspectives for development. Therefore, it is necessary to continuously invest in sustainable development through the development and implementation of development projects and upcoming technologies:

- Biogas plants - are important for the sustainable development of agriculture, environmental protection, development of new products and improvement of quality of life;

- Solar energy - is a source of clean energy and provides a strong impetus to the technological development of the local economy and to increase the competitiveness of the local product;

- Biomass plants - enable efficient protection, maintenance, and cultivation of the environment, especially important for sustainable agriculture;

- Decentralized sewage and sewage treatment systems - allow for the phased development of local sewage and sewage treatment systems.

So, renewable energy and the use of clean technologies are being developed through a series of smaller projects that generate development opportunities and benefits:

- Preserving and cultivating the human environment;

- Strengthening economic and economic activity;

- Diversification and job creation;

- Strengthening local technological capacity;

- Strengthening the competitiveness of the local product;

- Creating long-term development perspectives; 
- Improving the quality of life in the local community.

\section{Conclusions}

Based on our research into the possibilities of regional sustainability of local and rural development and elaboration of the good experiences of developed European countries, we can draw some conclusions:

- Sustainable development of local and rural communities is a key priority of EU Member States as well as other countries in the process of stabilization and association;

- The European Union strongly supports sustainable development, allocating around $40 \%$ of the funds from the rural development budget, as an important component of sustainable development;

- According to European standards, sustainable development is the responsibility of local communities, and this practice is accepted by most countries in the region;

- The main task of local communities is to identify their development opportunities, define their development mission, vision and goals, adopt strategic plans and design and implement sustainable development programs and projects;

- An innovative approach to creating sustainable development significantly improves the competitiveness of the local community;

- Sustainable local - rural development is based the continuous implementation of various activities in the fields of preservation and development integration of human environment, natural, cultural and traditional heritage (local capital), communal and social infrastructure, economic development and improvement of standards and quality of life, and rational renewable energy management and clean technologies;

- Some countries in the region do not yet have an approved development strategy or a sustainable development strategy, without which it is not possible to seriously create sustainable development and develop detailed sectoral strategic plans;

- Local communities in the countries of the region must insist on the adoption of development strategies and sustainable development strategies to align their development priorities with the development priorities of the state and entities;

- Local community development strategies touch superficially on sustainable development issues;

- All countries in the region generally have high quality natural, cultural and traditional heritage, as well as respectable renewable resources, whose rational management could fulfill the basic requirement of sustainable development: "to leave the future with more than we inherited from the past!"

\section{Conflict of interests}

The authors declare no conflict of interest. 


\section{References}

1. Barbier,E. B., \& Markandya,A. (1989). The conditions for achieving environmentally sustainable development (Vol. 89, No. 1). London Environmental Economics Centre.

2. Beard, T.R., Lozada, G . (1999), Economics, Entropy and the Environment Cheltenham, Edward Elager, UK,

3. Bogdanov N., (2007). Small rural households in Serbia and rural non-agricultural economy, UNDP, Ministry of Agriculture, Forestry and Water Management, Belgrade.

4. Đokić, M. (2019). Sustainable agricultural and rural development in the European Union. Economics of sustainable development, 3(1), 29-43.

5. European Commission Report (2016), Communication from the commission to the European Parliament, the council, the European Economic and Social Committee and the committee of the regions, Strasbourg, Retrieved from https://eur-lex.europa. eu (November 5, 2019)

6. European Commission (2011). Agriculture and Rural Development. Rural areas and the Europe 2020 strategy: employment. Brussels: EC. Retrieved from: https://eurlex.europa.eu (November 6, 2019)

7. Jovanović, M., Rađenović, T., \& Stanojević, J. (2018). Human capital as the determinant of the development of the EU rural areas. Ekonomski izazovi, 7(13), 1-16. doi: 10.5937/EkoIzazov1813001J

8. Krstić, B., Sekulić, V., Jovanović, M. (2018): Evolutionary approach in the theory of sustainable development, Economics of sustainable development, 2(1), 17-31

9. Ministry of Agriculture, Forestry and Water Management: Strategy of Agriculture and Rural Development of the Republic of Serbia for the period 2014-2024., the Government Republic of Serbia, Retrieved from https://www.fren.org.rs (November 2, 2019)

10.Pejanović R., Njegovan Z., Tica N., (2007),. Transition Rural Development and Agrarian Policy, Monography, Faculty of Agriculture, Novi Sad.

11. Schwab K., (2017): The Global Competitiveness Report 2016-2017, World Economic Forum, Geneva, Retrieved from http://www3.weforum.org/ (November 12, 2019)

12. Schwab K., (2018) The Global Competitiveness Report 2017-2018, World Economic Forum, Geneva, Retrieved from http://www3.weforum.org/ (November 18, 2019)

13. Tanaskovic. S. (2018). Competitive position Serbia in 2018 according to World Economic Forum reports. Retrieved November 3, 2019, from https://www.fren.org.rs 14.RS Official Gazette", No. 84/15, Government of Republic of Serbia. 